\title{
Efisiensi Penggunaan Nitrogen pada Padi Gogo Varietas IPB 9G
}

\section{The Nitrogen Use Efficiency of an Upland Rice IPB 9G}

\author{
Suwarto $^{1^{*}}$, Defiyanto Djami Adi ${ }^{2}$, Iskandar Lubis ${ }^{1}$, dan Sugiyanta ${ }^{1}$ \\ ${ }^{1}$ Departemen Agronomi dan Hortikultura, Fakultas Pertanian, Institut Pertanian Bogor \\ (IPB University), Jl. Meranti, Kampus IPB Darmaga, Bogor 16680, Indonesia \\ ${ }^{2}$ Akademi Komunitas Negeri Sabu Raijua \\ Jl. Trans Seba, Sabu Barat, Sabu Raijua, Nusa Tenggara Timur, Indonesia
}

Diterima 7 Desember 2020/Disetujui 24 Maret 2021

\begin{abstract}
Rice is a major staple food in Indonesia. Some new upland rice varieties have been released and should be accompanied by accurate fertilization dosage at a specific location. One of the fertilizers is nitrogen $(N)$. The objective of this research was to evaluate $N$ use efficiency in upland rice variety IPB $9 G$ as a response to $N$ dose. The $N$ doses were $0,46,92,138$, and $184 \mathrm{~kg} \mathrm{~N} \mathrm{ha}^{-1}$ (using urea 46\% N). The experiment was conducted using a randomized complete block design with three replications in Darmaga, Bogor in March-July 2018. The plot size of each $N$ dose was $3.5 \mathrm{~m} x 3.0 \mathrm{~m}$. The $\mathrm{N}$ use efficiency was determined through rice growth, $N$ uptake, agronomical and physiological efficiency. Plant height and tiller number increased followed the increase of $N$ dose. The $N$ uptake and grain yield had a quadratic response to the $N$ dose which could be an indicator of the $N$ fertilizing efficiency. The maximum $N$ uptake and grain yield were achieved at an average of 143.8 $\mathrm{kg} \mathrm{N} \mathrm{ha-1}$ (312.5 $\mathrm{kg}$ urea ha $\left.\mathrm{h}^{-1}\right)$. The recommendation of $N$ fertilizing for soil with moderately $N(0.27 \%)$ during the dry season was $143.8 \mathrm{~kg} \mathrm{~N} \mathrm{ha}^{-1}\left(312.5 \mathrm{~kg}\right.$ urea $\left.\mathrm{ha}^{-1}\right)$, as it is the most efficient dose in IPB $9 \mathrm{G}$ cultivation.
\end{abstract}

Keywords: agronomical efficiency, grain yield, $N$ uptake, physiological efficiency

\section{ABSTRAK}

Beras merupakan makanan pokok di Indonesia. Beberapa varietas padi gogo unggul baru telah dilepas dan perlu dilengkapi pemupukan yang akurat di lokasi tertentu. Salah satu jenis pupuk tersebut adalah nitrogen (N). Penelitian ini bertujuan untuk mengetahui efisiensi penggunaan N pada padi gogo IPB $9 G$ sebagai respon terhadap dosis pupuk $N$. Dosis pupuk yang diaplikasikan adalah 0, 46, 92, 138, dan $184 \mathrm{~kg} \mathrm{~N} \mathrm{ha}^{-1}$ dalam bentuk urea (46\% N). Percobaan dilakukan menggunakan rancangan acak kelompok dengan 3 ulangan di Darmaga, Bogor pada Maret-Juli 2018. Petak percobaan berukuran $3.5 \mathrm{~m} \times 3.0 \mathrm{~m}$. Padi gogo ditanam dengan jarak $50 \mathrm{~cm} \times 10 \mathrm{~cm}$. Efisiensi penggunaan N dinilai dari pertumbuhan padi, serapan $N$, efisiensi agronomi dan fisiologis. Peningkatan tinggi tanaman dan jumlah anakan mengikuti peningkatan dosis $N$. Serapan $N$ dan hasil gabah memiliki respon kuadratik terhadap dosis $N$ dan dapat menjadi indikator efisiensi pemupukan $N$. Serapan $N$ dan hasil gabah yang maksimum diperoleh dari dosis pupuk $N$ yang hampir sama, rata-rata 143.8 $\mathrm{kg} \mathrm{N} \mathrm{ha-1} \mathrm{(312.5} \mathrm{kg}$ urea ha $\left.\mathrm{h}^{-1}\right)$. Untuk efisiensi pemupukan N padi gogo IPB 9G pada tanah dengan $N$ total sedang (0.27\%) di musim kering dapat diaplikasikan $143.8 \mathrm{~kg} \mathrm{~N} \mathrm{ha-1}^{-1}$ (urea $312.5 \mathrm{~kg} \mathrm{~N} \mathrm{ha}^{-1}$ ).

Kata kunci: efisiensi agronomis, efisiensi fisiologis, hasil biji, serapan N

\section{PENDAHULUAN}

Beras merupakan makanan pokok utama di Indonesia. Pertumbuhan penduduk perlu diikuti dengan produksi beras. Produksi beras ini didominasi oleh produksi di lahan sawah. Namun, luas lahan sawah sudah sangat terbatas. Lahan yang masih berpotensi untuk memproduksi padi adalah lahan

\footnotetext{
* Penulis untuk korespondensi. e-mail: warto_skm@apps.ipb. ac.id
}

kering dengan budidaya padi gogo. Balitbangtan (2014) melaporkan bahwa Indonesia memiliki 33 juta hektar lahan potensial untuk tanaman pangan dan diantaranya sekitar 1 juta hektar lahan telah ditanami padi gogo. Varietas IPB 9G merupakan salah satu padi gogo yang telah dilepas tahun 2017 dengan SK Menteri Pertanian: 335/Kpts/TP.030/5/2017 (Kementan, 2017). Varietas-varietas baru termasuk IPB 9G perlu dilengkapi dengan praktik budidaya yang baik (good agricultural practices/GAP) untuk mencapai produktivitas maksimum, salah satunya adalah ketepatan pemupukan nitrogen. 
Unsur hara $\mathrm{N}$ memiliki peran penting dalam fungsi biokimia dan fisiologis tumbuhan. Semua proses vital pada tumbuhan dikaitkan dengan protein, dan unsur nitrogen merupakan penyusun esensialnya (Leghari et al., 2016). Widowati et al. (2011) melaporkan oleh bahwa petani lebih memilih untuk menggunakan pupuk nitrogen (urea) daripada pupuk hara lainnya seperti $\mathrm{P}$ dan $\mathrm{K}$, karena respon dari aplikasi $\mathrm{N}$ yang cepat dan tinggi pada tanaman. Akibatnya, penggunaan pupuk N sering tidak efisien. Studi kasus di Kediri-Jawa Timur melaporkan bahwa sebagian besar petani biasanya menggunakan urea sekitar 400 - 500 $\mathrm{kg} \mathrm{ha}^{-1}$ dan $600 \mathrm{~kg} \mathrm{ha}^{-1}$, masing-masing untuk padi sawah dan jagung (Widowati et al., 2011).

Nitrogen adalah hara tanaman yang penting dan biasanya sangat sering kekurangan pada penamanan serealia monokultur (Omara et al., 2019). Masclaux-Daubresse et al. (2010) menyatakan bahwa produksi pertanian memerlukan pupuk nitrogen dalam jumlah banyak, perbaikan efisiensi penggunaan nitrogen pada tanaman menjadi kunci penting dalam peningkatan produksi pertanian.

Menurut Widowati et al. (2011) lahan kering untuk padi gogo pada umumnya bervariasi kemiringannya, berbeda dengan padi sawah yang umumnya di lahan yang datar. Pengelolaan $\mathrm{N}$ di lahan kering yang umumnya berkemiringan menjadi hal yang penting untuk dilakukan. Kehilangan $\mathrm{N}$ melalui beberapa proses seperti penguapan, aliran permukaan, dan pencucian tidak dapat dihindari. Oleh karena itu, peningkatan efisiensi pemupukan N pada lahan padi gogo perlu dilakukan untuk pengembangan pertanian padi gogo di Indonesia.

Informasi tentang dosis aplikasi pupuk $\mathrm{N}$ pada padi gogo masih sedikit karena usahataninya kurang intensif dibandingkan padi sawah. Beberapa penelitian menggunakan dosis pupuk $\mathrm{N}$ umum yang ditetapkan oleh para peneliti di negara lain. Diantaranya seperti yang dilakukan Adi et.al. (2018) yang mengacu pada Dobermann dan Fairhaust (2000) dalam menentukan dosis nitrogen optimum pada varietas padi gogo unggul baru di Bogor. Selain itu, Arrasyid (2019) menggunakan $150 \mathrm{~kg}$ urea ha-1 sebagai dosis dasar aplikasi $\mathrm{N}$ dalam penelitiannya untuk varietas lokal Kalimantan di Bogor. Fageria et al. (2014) menyampaikan bahwa dosis aplikasi $\mathrm{N}$ yang efektif dapat dievaluasi dengan menghitung serapan nitrogen dan efisiensi penggunaan nitrogen. Namun, efisiensi penggunaan nitrogen ditentukan pula oleh indikator agronomis dan fisiologis (Yang et al., 2019). Oleh karena itu, penetapan dosis aplikasi pupuk $\mathrm{N}$ yang efektif berdasarkan varietas dan lokasi ekosistem yang spesifik menjadi penting dalam pengembangan padi gogog di Indonesia. Penelitian ini dilakukan untuk menentukan efisiensi penggunaan pupuk $\mathrm{N}$ dari berbagai dosis aplikasi pupuk $\mathrm{N}$ pada padi gogo varietas IPB 9G.

\section{BAHAN DAN METODE}

Percobaan lapangan dilakukan di Kebun Percobaan Sawah Baru, Departemen Agronomi dan Hortikultura, Fakultas Pertanian, Institut Pertanian Bogor, Jawa Barat. Percobaan dilaksanakan pada bulan Maret sampai dengan
Juli 2018. Tanah yang digunakan memiliki pH 5.0, dengan kandungan C-organik 1.77\%, N-total 0.27\%, $\mathrm{P}_{2} \mathrm{O}_{5} 7.0$ ppm, kapasitas tukar kation 19.21 meq 100 g-1 kalsium (Ca) 6.94 meq $100 \mathrm{~g}^{-1}$, magnesium $(\mathrm{Mg}) 1.62 \mathrm{meq} 100 \mathrm{~g}^{-1}$, kalium (K) 0.16 meq $100 \mathrm{~g}^{-1}$, dan natrium $(\mathrm{Na}) 2.30 \mathrm{meq} 100 \mathrm{~g}^{-1}$. Kandungan $\mathrm{N}$ total tanah tergolong sedang (Eviati dan Sulaeman, 2009).

Percobaan dilakukan di petak-petak percobaan di lapangan. Dosis pupuk N yang diaplikasikan adalah 0,46 , 92, 138, dan $184 \mathrm{~kg} \mathrm{~N} \mathrm{ha}^{-1}(0,100,200,300$, dan $400 \mathrm{~kg}$ urea $\left.\mathrm{ha}^{-1}\right)$. Rancangan percobaan adalah rancangan acak kelompok dengan tiga ulangan. Varietas IPB 9G ditanam pada lahan seluas $3.5 \mathrm{~m}$ x $3.0 \mathrm{~m}$ pada setiap dosis $\mathrm{N}$ sebagai unit percobaan. Pada setiap lubang tanam diabur 5 benih padi jarak tanam $50 \mathrm{~cm}$ x $10 \mathrm{~cm}$ (Arinta dan Lubis, 2018) dan dipelihara menjadi satu rumpun. Pemupukan $\mathrm{N}$ diaplikasikan pada saat tanam (40\%), 4 minggu setelah tanam (30\%) dan 8 minggu setelah tanam (30\%). Pada saat tanam, setiap unit percobaan dipupuk dasar $37.8 \mathrm{~g} \mathrm{P}_{2} \mathrm{O}_{5}$ dan $63.0 \mathrm{~g} \mathrm{~K}_{2} \mathrm{O}$. Peubah pertumbuhan meliputi tinggi tanaman dan jumlah anakan diamati pada 3-8 minggu setelah tanam (MST). Kandungan N (\%) dalam bahan kering (BK) biomas jerami dan gabah dianalisis pada saat panen. Serapan N per rumpun dihitung sebagai perkalian antara kandungan $\mathrm{N}$ dan BK biomas jerami dan gabah.

Efisiensi penggunaan $\mathrm{N}$ ditentukan mengikuti Fageria et al. (2014) dengan menghitung efisiensi agronomis (EA) dan efisiensi fisiologis (EF). EA dihitung dengan rumus: $E A$ $\left(\mathrm{mg} \mathrm{mg}^{-1}\right)=(G f-G u) / N a$.

Dimana:

Gf: hasil gabah dari rumpun yang dipupuk N (mg), Gu: hasil gabah dari rumpun yang tidak dipupuk N (mg), Na: jumlah pupuk $\mathrm{N}$ yang diaplikasikan (mg). EP dihitung dengan rumus: $E P\left(\mathrm{mg} \mathrm{mg}^{-1}\right)=(B Y f-B Y u) /(N f-N u)$; Dimana:

$B Y f$ : hasil biologis (gabah dan jerami) dari rumpun yang dipupuk $\mathrm{N}$ (mg), BYu: hasil biologis (gabah dan jerami) dari rumpun yang tidak dipupuk $\mathrm{N}(\mathrm{mg}), N f$ : serapan hara (gabah dan jerami) dari rumpun yang dipupuk N (mg), $N u$ : serapan $\mathrm{N}$ (gabah dan jerami) dari rumpun yang tidak dipupuk N (mg).

Data semua variabel yang diamati dianalisis menggunakan analisis ragam untuk mengevaluasi pengaruh dosis N. Analisis Duncan's Multi Range Test pada taraf $5 \%$ digunakan untuk membedakan nilai tengah antar dosis N. Uji ortogonal polinomial dilakukan untuk mengetahui respon beberapa peubah terhadap dosis pupuk $\mathrm{N}$.

\section{HASIL DAN PEMBAHASAN}

Penelitian dilakukan pada tanah dengan kandungan $\mathrm{N}$ total sedang $(0.27 \%)$ dan musim kering, yang memiliki rata-rata curah hujan $52.5 \mathrm{~mm} /$ bulan, suhu $26.0-26.7^{\circ} \mathrm{C}$, dan kelembaban nisbi $81-86 \%$. Hasil penelitian menujukkan bahwa dosis pupuk $\mathrm{N}$ memberikan pengaruh sangat nyata pada pertumbuhan padi, bobot kering biomas, dan hasil gabah. Hal demikian juga dilaporkan oleh Rusdiyansah dan Saleh (2017) untuk dua kultivar padi lokal Kalimantan yang diuji. 


\section{Pertumbuhan Padi}

Beberapa peubah utama pertumbuhan padi adalah tinggi tanaman, jumlah gabah per malai, dan bobot 1,000 butir biji (Maqueira-López et al., 2019). Hasil pengamatan menunjukkan bahwa pertambahan tinggi tanaman selaras dengan pertambahan umur tanaman. Jumlah anakan maksimum pada perlakuan 138 dan $184 \mathrm{~kg} \mathrm{~N} \mathrm{ha}^{-1}$ (300 dan $400 \mathrm{~kg}$ urea ha-1) lebih banyak dibandingkan tanaman pada perlakuan dengan dosis pupuk $\mathrm{N}$ yang lebih rendah (Gambar 1). Jumlah anakan paling banyak adalah 15.2 anakan. Huyly et al. (2011) menunjukkan bahwa jumlah anakan padi dengan beberapa cara pemupukan berkisar antara 14-18 anakan. Hussain et al. (2016) menghasilkan tinggi tanaman 97.1-99.9 cm dan 11.6-14.3 jumlah anakan per rumpun dari padi gogo yang diaplikasikan dengan beberapa dosis pupuk nitrogen, serta penelitian Rusdiyansyah dan Saleh (2017) menghasilkan 13-16 anakan per rumpun.

Tinggi tanaman pada akhir fase vegetatif dari berbagai dosis N berkisar 96.8-108.9 cm. Berdasarkan deskripsi varietas (Kementan RI, 2017), IPB-3G memiliki ratarata tinggi tanaman $98 \mathrm{~cm}$ dan jumlah anakan 12 anakan. Pertumbuhan vegetatif tanaman padi pada semua dosis $\mathrm{N}$ tergolong normal. Gambar 1 menunjukkan adanya peran unsur N pada pertumbuhan padi gogo. Leghari et al. (2016) menyatakan bahwa nitrogen merupakan salah satu unsur hara esensial yang dibutuhkan dalam pembentukan protein untuk pertumbuhan tanaman. Semakin banyak nutrisi N yang ditambahkan melalui pemupukan akan mensuplai nitrogen yang tinggi untuk produksi protein dan pertumbuhan tanaman. Pada tanaman padi nitrogen memacu pertumbuhan tanaman yang cepat, meningkatkan hasil dan kualitas gabah melalui jumlah anakan yang lebih banyak, perluasan daun, pembentukan biji, pengisian biji, dan sintesis protein.

\section{Hasil Padi dan Serapan Nitrogen}

Bobot kering (BK) biomas jerami dan gabah saat panen dipengaruhi secara nyata oleh dosis pupuk N. Bobot kering jerami dan gabah per rumpun pada tanaman tanpa pupuk nitrogen $\left(0 \mathrm{~kg} \mathrm{~N} \mathrm{ha}^{-1}\right)$ menunjukkan hasil paling rendah. BK biomas jerami dan gabah menunjukkan peningkatan seiring dengan meningkatnya dosis $\mathrm{N}$ hingga $92 \mathrm{~kg} \mathrm{~N} \mathrm{ha}^{-1}$, selanjutnya relatif tetap sampai dosis $\mathrm{N}$ tertinggi (Tabel 1). Tidak ada pengaruh nyata dosis $\mathrm{N}$ terhadap kandungan $\mathrm{N}$ pada jerami dan gabah. Kandungan $\mathrm{N}$ dalam $\mathrm{BK}$ biomas jerami dan gabah berkisar $0.69-0.76 \%$ sesuai dengan hasil penelitian Dobermaan dan Fairhurst (2002) yang menyatakan bahwa bahan kering jerami padi mengandung $0.5-0.8 \% \mathrm{~N}$, walaupun hasil penelitian Malav dan Ramani (2016) menunjukkan kisaran lebih tinggi dengan kandungan $0.89-1.13 \% \mathrm{~N}$ dalam jerami padi sawah.

Berdasarkan BK biomas jerami dan gabah serta kandungan $\mathrm{N}$ nya, dihasilkan nilai serapan $\mathrm{N}$ seperti ditunjukkan pada Tabel 1. Serapan N padi gogo 'IPB 9G' menunjukkan pola respon kuadratik terhadap peningkatan dosis pupuk $\mathrm{N}$ seperti pada Gambar 2 dengan mengikuti persamaan fungsi $\mathrm{Y}=-9.7972 \mathrm{X}^{2}+73.091 \mathrm{X}+76.661\left(\mathrm{R}^{2}=\right.$ $0.9929)$; Y adalah serapan N (mg per rumpun) dan X adalah dosis N (mg per rumpun). Serapan $\mathrm{N}$ maksimum dicapai pada dosis pupuk $643.5 \mathrm{mg} \mathrm{N}$ per rumpun (128.7 $\mathrm{kg} \mathrm{N}$ ha $^{-1}$ atau $279.8 \mathrm{~kg}$ urea ha- ${ }^{-1}$ ).

Hasil gabah juga menunjukkan pola respon kuadratik terhadap peningkatan dosis $\mathrm{N}$ (Gambar 2) mengikuti persamaan fungsi $\mathrm{Y}=-3.79 \mathrm{X}^{2}+32.05 \mathrm{X}+31.15\left(\mathrm{R}^{2}=\right.$ $0.5579)$; $\mathrm{Y}$ adalah hasil gabah (mg per rumpun) dan $\mathrm{X}$ adalah dosis $\mathrm{N}$ (mg per rumpun). Hasil gabah maksimum dihasilkan dari padi yang dipupuk $729.4 \mathrm{mg} \mathrm{N}$ per rumpun $\left(158.8 \mathrm{~kg} \mathrm{~N} \mathrm{ha}^{-1}\right.$ atau $345.2 \mathrm{~kg}$ urea ha $\left.^{-1}\right)$.

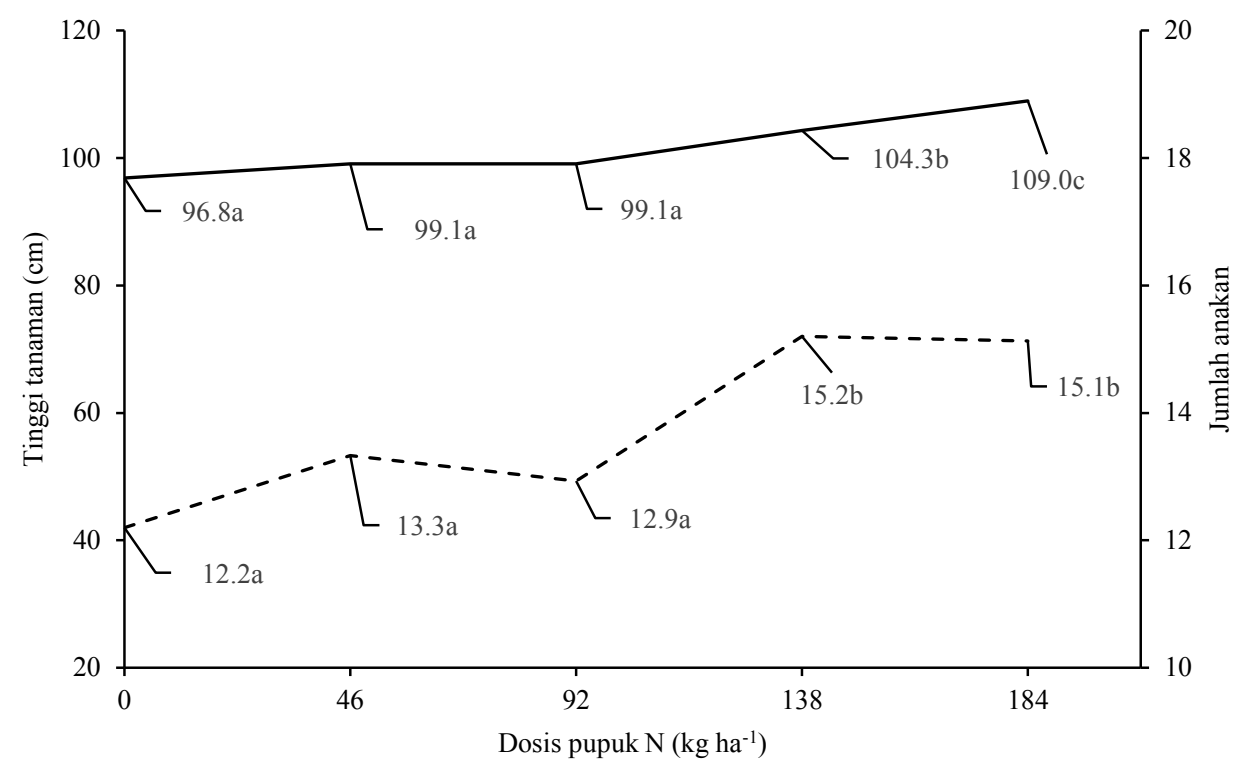

Gambar 1. Tinggi tanaman dan jumlah anakan padi gogo IPB 9G umur 8 MST pada berbagai dosis pupuk N (angka yang diikuti oleh huruf yang sama tidak berbeda nyata berdasarkan DMRT taraf 5\%) 
Tabel 1. Hasil padi gogo IPB 9G dan serapan N pada berbagai dosis $\mathrm{N}$

\begin{tabular}{|c|c|c|c|c|c|c|}
\hline \multicolumn{2}{|c|}{ Dosis N } & \multirow{2}{*}{$\begin{array}{l}\text { BK jerami dan } \\
\text { gabah } \\
\text { (g per rumpun) }\end{array}$} & \multirow{2}{*}{$\begin{array}{c}\text { Kandungan } \mathrm{N} \\
\text { jerami dan gabah } \\
(\%)\end{array}$} & \multirow{2}{*}{$\begin{array}{l}\text { Bobot gabah } \\
\text { (g per rumpun) }\end{array}$} & \multirow{2}{*}{$\begin{array}{c}\text { Bobot gabah } \\
\text { ubinan* }\left(\mathrm{g} \mathrm{m}^{-2}\right)\end{array}$} & \multirow{2}{*}{$\begin{array}{c}\text { Serapan } \mathrm{N} \\
\text { (mg per rumpun) }\end{array}$} \\
\hline $\mathrm{kg} \mathrm{ha}^{-1}$ & mg per rumpun & & & & & \\
\hline 0 & 0 & $20.4 c$ & 0.69 & $49.7 \mathrm{c}$ & $528.8 \mathrm{c}$ & $140.4 \mathrm{c}$ \\
\hline 46 & 230 & $24.9 b$ & 0.73 & $100.7 \mathrm{a}$ & $623.0 \mathrm{~b}$ & $181.6 \mathrm{~b}$ \\
\hline 92 & 460 & $28.2 \mathrm{a}$ & 0.75 & $89.4 b$ & $670.6 \mathrm{a}$ & $211.3 \mathrm{a}$ \\
\hline 138 & 690 & $27.6 \mathrm{a}$ & 0.76 & $83.2 b$ & $707.1 \mathrm{a}$ & $209.7 \mathrm{a}$ \\
\hline 184 & 920 & $28.7 \mathrm{a}$ & 0.69 & $105.1 \mathrm{a}$ & $689.1 \mathrm{a}$ & $197.9 \mathrm{ab}$ \\
\hline
\end{tabular}

Keterangan: Angka di dalam kolom yang sama yang diikuti huruf yang sama tidak berbeda nyata berdasarkan uji DMRT pada taraf 5\%. $\mathrm{BK}=$ bobot kering; $*$ ukuran ubinan $=1 \mathrm{~m} \mathrm{x} 1 \mathrm{~m}$

Adanya pola respon yang sama antara serapan $\mathrm{N}$ dan hasil gabah terhadap peningkatan dosis pupuk N (Gambar 2) menunjukkan adanya korelasi positif antar kedua peubah. Fageria et al. (2020) melaporkan bahwa terdapat korelasi positif yang sangat nyata antara serapan $\mathrm{N}$ dalam biomas jerami dan gabah dengan hasil gabah pada 19 genotipe padi gogo yang diuji. Serapan N yang tinggi menyebabkan jumlah $\mathrm{N}$ yang tersedia untuk sintesis protein dalam pertumbuhan lebih tinggi (Leghari et al., 2016). Semakin tinggi serapan $\mathrm{N}$ pertumbuhan padi akan meningkat yang diantaranya ditunjukkan oleh meningkatnya biomassa dan hasil gabah.

\section{Efisiensi Agronomis dan Efisiensi Fisiologis}

Fageria et al. (2014) menyampaikan bahwa EA didefinisikan sebagai produksi ekonomi yang diperoleh per unit hara $\mathrm{N}$ yang digunakan. Efisiensi fisiologis didefinisikan sebagai hasil biologis yang diperoleh per unit serapan hara $\mathrm{N}$ yang mengukur kemampuan tanaman untuk menghasilkan biji dan biomassa dengan $\mathrm{N}$ yang diperoleh di seluruh bagian tanaman. EA dan EF secara signifikan dipengaruhi oleh dosis $\mathrm{N}$ yang diberikan. Nilai EA menurun saat padi gogo IPB 9G dipupuk sampai dosis $690 \mathrm{mg}$ N per rumpun (138 $\mathrm{kg} \mathrm{N}$ ha $^{-1}$ atau $300 \mathrm{~kg}$ urea ha $\left.{ }^{-1}\right)$. Nilai EF mulai meningkat saat dipupuk dengan dosis $460 \mathrm{mg}$ N per rumpun (92 $\mathrm{kg} \mathrm{N} \mathrm{ha}^{-1}$ atau $200 \mathrm{~kg}$ urea ha-1) sampai dosis paling tinggi (Tabel 2). Respon EF (Y) terhadap dosis pupuk N (X) bersifat kuadratik (Gambar 3) dengan persamaan $\mathrm{Y}=$ 9.9848X2-39.994X+142.53 $\left(\mathrm{R}^{2}=0.8659\right)$. Hal ini sesuai yang dilaporkan Devika et al. (2018) bahwa EF meningkat dengan meningkatnya dosis $\mathrm{N}$ yang mencerminkan peningkatan pemanfaatan nitrogen terserap oleh tanaman padi. Peningkatan EF ini diikuti oleh peningkatan nilai serapan $\mathrm{N}$ dan hasil gabah (Gambar 2). Nilai keduanya mendekati maksimum pada dosis rata-rata $143.8 \mathrm{~kg} \mathrm{~N}^{-1}$ (312 kg urea ha-1).

Analisis regresi EA (Y) terhadap dosis $\mathrm{N}(\mathrm{X})$ menghasilkan respon kuadratik dengan persamaan $\mathrm{Y}$ $=36.798 X 2-236.23 \mathrm{X}+418.71\left(\mathrm{R}^{2}=0.9939\right)$ seperti pada Gambar 3. EA menunjukkan penurunan dengan meningkatnya dosis pupuk nitrogen dari 230-690 mg N per

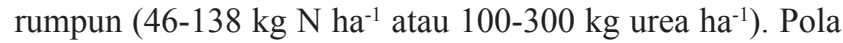
respon penurunan EA terhadap peningkatan dosis pupuk dari 40-160 kg N ha ${ }^{-1}$ juga diperoleh dalam penelitian Contreras et al. (2017). Respon EA yang tidak seiring dengan respon EF pada peningkatan dosis pupuk $\mathrm{N}$ juga dilaporkan oleh Fageria et al. (2014).

Perubahan lingkungan pertumbuhan, termasuk tingkat ketersediaan nitrogen, akan mempengaruhi sifat agronomis dan proses fisiologis; respon sifat agronomis adalah mirip dengan respon proses fisiologis (Mohan dan Gupta, 2015). Dengan demikian tinggi tanaman, jumlah anakan dan hasil gabah yang semakin tinggi pada tingkat dosis pupuk $\mathrm{N}$ yang tinggi (Gambar 1 dan 2) dalam penelitian ini adalah didukung oleh meningkatnya proses fisiologis atau EF (Tabel 2 dan Gambar 3).

Semakin tinggi dosis pupuk N maka semakin banyak nitrogen yang diserap per rumpun (Gambar 2) untuk menghasilkan total biomassa sehingga nilai EF meningkat

Tabel 2. Efisiensi agronomis dan efisiensi fisiologis padi gogo IPB 9G pada berbagai dosis N

\begin{tabular}{lccc}
\hline & Dosis N & $\begin{array}{c}\text { Efisiensi agronomis } \\
\left(\mathrm{mg} \mathrm{mg}^{-1}\right)\end{array}$ & $\begin{array}{c}\text { Efisiensi fisiologis } \\
\left(\mathrm{mg} \mathrm{mg}^{-1}\right)\end{array}$ \\
\hline 0 & mg per rumpun & - & - \\
46 & 0 & $221.7 \mathrm{a}$ & $109.9 \mathrm{~b}$ \\
92 & 230 & $86.2 \mathrm{~b}$ & $110.4 \mathrm{~b}$ \\
138 & 460 & $48.5 \mathrm{~b}$ & $104.5 \mathrm{~b}$ \\
184 & 690 & $60.1 \mathrm{~b}$ & $144.9 \mathrm{a}$ \\
\hline
\end{tabular}

Keterangan: Angka di dalam kolom yang sama yang diikuti huruf yang sama tidak berbeda nyata berdasarkan uji DMRT pada taraf 5\% 


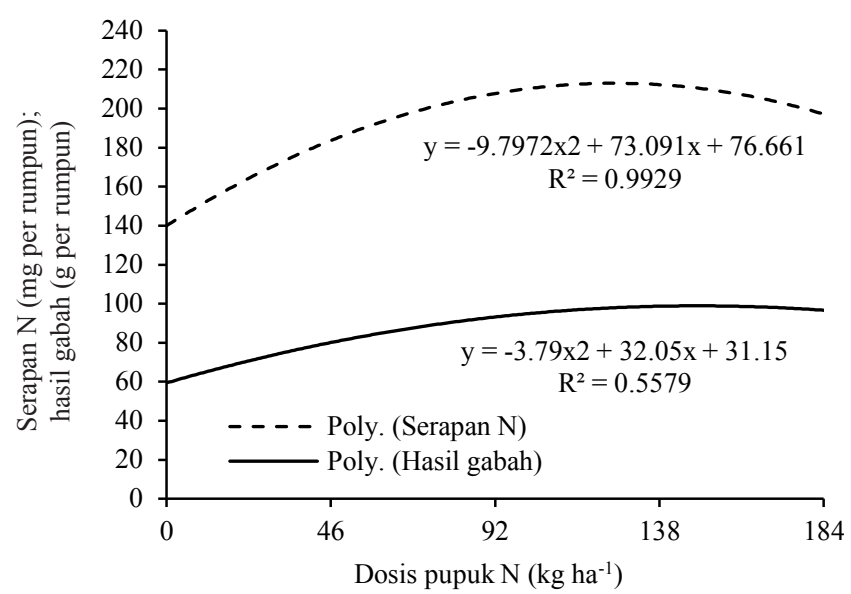

Gambar 2. Respon serapan N dan hasil gabah padi gogo IPB 9G pada berbagai dosis pupuk $\mathrm{N}$

(Gambar 3). Peningkatan serapan N juga diikuti oleh peningkatan hasil gabah sebagai produksi ekonomi (Gambar 2), walaupun bila dibandingkan dengan hasil gabah tanpa pemupukan maka nilai EA menurun (Gambar 3). Serapan hara $\mathrm{N}$ yang menentukan $\mathrm{EF}$ dan $\mathrm{EA}$, dan hasil gabah dapat dijadikan pertimbangan utama dalam menetapkan dosis yang efektif. Rata-rata dosis pupuk $\mathrm{N}$ yang menghasilkan serapan hara $\mathrm{N}$ dan hasil gabah mendekati maksimum adalah $143.8 \mathrm{~kg} \mathrm{~N}^{-1}$ (312.5 $\mathrm{kg}^{-1}$ urea ha $\left.{ }^{-1}\right)$ sehingga dosis ini merupakan yang paling efisien dalam pemupukan $\mathrm{N}$ pada padi gogo IPB 3G.

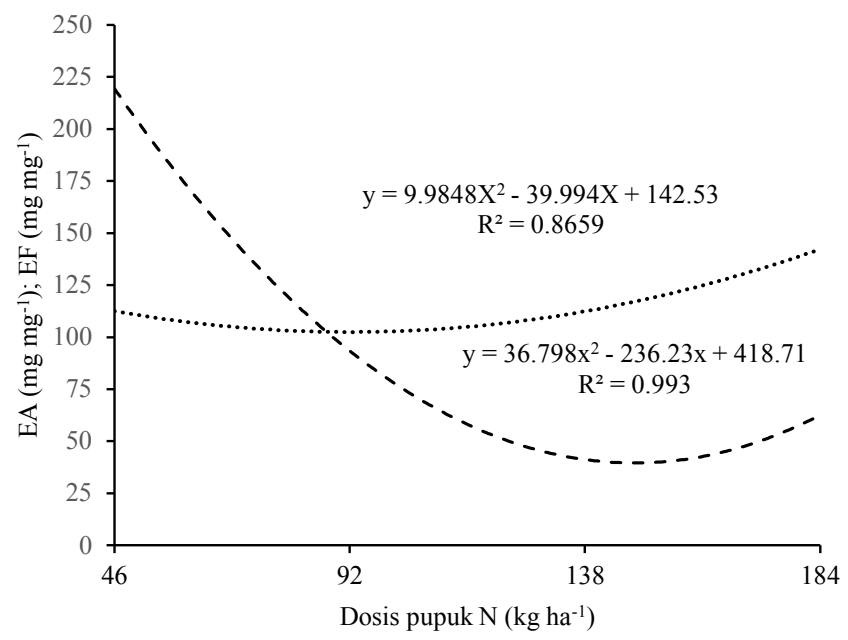

Gambar 3. Respon nilai efisiensi agronomis dan efisiensi fisiologis padi gogo IPB $9 \mathrm{G}$ pada berbagai dosis pupuk $\mathrm{N}$

\section{KESIMPULAN}

Peningkatan dosis $\mathrm{N}$ dari 0-184 kg N ha ${ }^{-1}(0-400 \mathrm{~kg}$ urea $\mathrm{ha}^{-1}$ ) diikuti peningkatan secara linier peubah tinggi tanaman dan jumlah anakan padi gogo varietas IPB 9G. Serapan N dan hasil gabah menunjukkan respon kuadratik terhadap peningkatan dosis $\mathrm{N}$ sehingga dapat dijadikan indikator untuk efisiensi pemupukkan N. Serapan N dan hasil gabah yang mendekati maksimum diperoleh dari dosis pupuk $\mathrm{N}$ yang hampir sama, rata-rata $143.8 \mathrm{~kg} \mathrm{~N}^{-1}$ (312.5 kg urea ha-1). Dosis tersebut merupakan yang paling efisien dalam pemupukan $\mathrm{N}$ untuk padi gogo IPB $9 \mathrm{G}$ di tanah dengan kandungan $\mathrm{N}$ total sedang $(0.27 \%)$ di musim kering.

\section{DAFTAR PUSTAKA}

Adi, D.D., I. Lubis, Suwarto, Sugiyanta. 2019. Determination of the optimum doses for $\mathrm{N}, \mathrm{P}$, and $\mathrm{K}$ fertilizer for upland rice variety IPB 9G. J. Trop. Crop Sci. 3:164173.

Arinta, K., I. Lubis. 2018. Pertumbuhan dan produksi beberapa kultivar padi lokal Kalimantan. Bul. Agrohorti. 6:260-270. Doi:10.29244/agrob. v6i2.18943.

Arrasyid, B., I. Lubis, Suwarto, H. Purnamawati. 2019. Penentuan dosis N, P, dan K optimum untuk padi gogo kultivar Mayas Lokal Kalimantan. J. Agron. Indonesia 48:8-14. Doi:10.24831/jai.v48i1.29213.

[Balitbangtan] Badan Penelitian dan Pengembangan Pertanian. 2014. Roadmap Pengembangan Lahan Kering. Balai Besar Sumber Daya Lahan Pertanian. Kementerian Pertanian Indonesia, Bogor, ID.

Contreras, H.A.S., R.R. Barzan, M.S. Contreras, O.R. Brito. 2017. Growth, yield and agronomic efficiency of rice (Oryza sativa L.) cv. IAPAR 117 affected by nitrogen rates and sources. Acta Agron. 66:558-565. Doi: 10.15446/acag.v66n4.59101.

Devika, S., V. Ravichandran, P. Boominathan. 2018. Physiological analyses of nitrogen use efficiency and yield traits of rice genotypes. Indian J. Plant Physiol. 23:100-110.

Dobermann, A., T.H. Fairhurst. 2002. Rice Straw Management. Better Crop International. Special Suplement 16:7-11.

Eviati, Sulaeman. 2009. Analisis Kimia Tanah, Tanaman, dan Pupuk. Edisi kedua. Balai Penelitian Tanah, Bogor, ID.

Fageria, N.K., A. Moreira, L.A.C. Moraes, M.F. Moraes. 2014. Nitrogen uptake and use efficiency in upland rice under two nitrogen sources. Comm. Soil Sci. Plant Anal. 45:461-469.

Fageria, N.K., O.P. de Morais, A.B. dos Santos. 2020. Nitrogen use efficiency in upland rice genotypes. J. Plant Nutr. 33:1696-1711. Doi:10.1080/01904167.2 010.496892 . 
Hussain, J., M.A. Siddique, M.M. Mia, G.N. Hasan, A.S. Seajuri, M.R. Malik, E. Zaman. 2016. Effect of different doses of nitrogen fertilizer on $\mathrm{T}$. aman rice. Int. J. Business Soc. Sci. Res. 4:328-332.

Huyly, T., S. Kasem, M. Chaiwat, A. Aram. 2011. Comparison between organic, GAP and chemical methods for cultivation of rice varities in Cambodia. J. Agric. Technol. 7:1435-1441.

[Kementan RI] Kementerian Pertanian Republik Indonesia. 2017. Deskripsi Padi Gogo Varietas IPB 9G. SK Menteri Pertanian No. 335/Kpts/TP.030/5/2017.

Leghari, S.J., N.A. Wahocho, G.M. Laghari, A.H. Laghari, G.M. Bhabhan, K.H. Talpur, T.A. Bhutto, S.A. Wahocho, A.A. Lashari. 2016. Role of nitrogen for plant growth and development: A Review. Adv. Environ. Biol. 10:209-218.

Malav, J. K., V. P. Ramani 2016. Yield and nutrient content of rice as influenced by silicon and nitrogen application. Res. J. Chem. Environ. Sci. 4:46-49.

Maqueira-López, L.A., R. Morejón-Rivera, O. RojánHerrera, W. Torres-de-la-Noval. 2019. Relationship between growth traits and yield formation in Indica-type rice crop. Agron. Mesoam. 230:79-100. Doi:10.15517/ma.v30i1.29671.

Masclaux-Daubresse, C., F. Daniel-Vedele, J. Dechorgnat, F. Chardon, L. Gaufichon, A. Suzuki. 2010.
Nitrogen uptake, assimilation and remobilization in plants: challenges for sustainable and productive agriculture. Ann. Bot. 105: 1141-1157. Doi:10.1093/ aob/mcq028.

Mohan, D., R.J. Gupta. 2015. Relevance of physiological efficiency in wheat grain quality and the prospects of improvement. Physiol. Mol. Biol. Plants. 21:591596. Doi:10.1007\%2Fs12298-015-0329-8.

Omara, P., L. Aula, W.R. Raun. 2019. Nitrogen uptake efficiency and total soil nitrogen accumulation in long-term beef manure and inorganic fertilizer application. Int. J. Agron. Vol. 2019, Article ID 9594369, 6 pages. Doi:10.1155/2019/9594369.

Rusdiyansyah, M. Saleh. 2017. The response of two local rice cultivars to different doses of nitrogen fertilizer in two paddy fields. AGRIVITA 39:137-144.

Widowati, L.R., D. Nursyamsi, S. Rochayati, M. Sarwani. 2011. Nitrogen management on agricultural land in Indonesia. Proc. of Int. Seminar on Increased Agricultural Nitrogen Circulation in Asia: Technological Challenge to Mitigate Agricultural N Emissions. Taipei, Taiwan, Sep. 27-28, 2011.

Yang, Y., S. Gao, Y. Jiang, Z. Lin, J. Luo, M. Li, J. Guo, Y. Su, L. Xu, Y. Que. 2019. The physiological and agronomic responses to nitrogen dosage in different sugarcane varieties. Front. Plant Sci. 10:1-18. Doi:10.3389/fpls.2019.00406. 